\title{
TOTAL IRON DETERMINATION IN DRINKING WATER USING STRIPPING VOLTAMETRY TECHNIQUE
}

\author{
Valeriu Robert Badescu ${ }^{1}$, Andrei Niculae ${ }^{1}$
}

${ }^{1}$ National Research and Development Institute for Industrial Ecology - ECOIND, 71-73 Drumul Podu Dambovitei Street, Sector 6, 060652, Bucharest, Romania, fax 021.4100575

\begin{abstract}
The paper describes the development and optimization of an analytical technique based on stripping voltammetry for iron determination in drinking water. The method is based on AdSV technique and HMDE electrode. Along with the complexing agent, the catechol, a pH buffering phosphate solution $(\mathrm{pH} \mathrm{7})$ is added. The reference electrode is $\mathrm{Ag} / \mathrm{AgCl} / \mathrm{KCl}$. The principle of the method is the following: iron complexation by the catechol, adsorption of the complex on the drop of the electrode followed by the stripping stage and practical resolubilization of the complex. Two concentration ranges were tested: from 10 to $50 \mu \mathrm{g} / \mathrm{L}$ and between 25 and $150 \mu \mathrm{g} / \mathrm{L}$. After calibration curves were plotted, real drinking water samples enriched with iron standard solution were analysed.

Laboratory test results indicate a very good recovery rate for the analytical trials performed (100.44\%, 104.07\%, 103.49\%). However, the average value of the recovery rate following all aditions and replicates - the precision grade is $102.66 \%$. The correlation factor between the two curves was 0.9936 for the interval of $10-50 \mu \mathrm{g} / \mathrm{l}$ and 0.9989 for the interval of $25-150 \mu \mathrm{g} / \mathrm{L}$. The optimised method can be easily applied in case of drinking water resources both surface and underground water.
\end{abstract}

Keywords: stripping voltammetry, iron speciation, $H M D E$

\section{Introduction}

Various techniques may be used for the determination of metals in water samples [1]. Given their toxicity of metals and ability to bioaccumulate [2], the legislation is imposing lower maximum concentration limits. Because of that reason analytical techniques with higher sensitivity and selectivity $[3,4]$ is needed. Electrochemical techniques are successfully suitable for such determinations having certain advantages: are simpler, sensitive, precise, present a fast response and imply lower financial costs [5-7]. Among these, electrochemical stripping voltammetry is frequently used $[8,9]$. Striping voltammetry allows not only the determination of trace iron in water but also the determination of iron species [10]. In this paper is presented a method based on stripping voltammetry for the determination of total iron and iron species in drinking water samples. It should be noted that in the case of iron, both Fe (II) and Fe (III) are electrochemically active. The iron is complexed by catechol. The complex formed is adsorbed on the drop of working electrode followed by the stripping step and practical resolving of the complex in solution. In addition to the complexing agent, which is catechol, a phosphate buffer solution is used. The pH of the buffer sollution is 7 . The reference electrode is $\mathrm{Ag} / \mathrm{AgCl} / \mathrm{KCl}$.

Next, to determine the iron species, the following steps are respected: bipyridyl is added to the water sample in order to selectively and totally complex and mask Fe (II). In this case, electrochemical signal will be given only by $\mathrm{Fe}$ (III). A reaction time of 20-30 minutes is required. 
In all literature studies is recommended to keep the natural $\mathrm{pH}$ of surface or drinking water as appropriate. Therefore, a sodium phosphate buffer solution with a $\mathrm{pH}$ of 7 is used. After the addition of buffer, the analysis is performed on the sample following the same procedure as for the determination of total iron. After determining the total iron and Fe (III) in the sample, the Fe (II) can be calculated.

Increasing the concentration of bipyridyl leads to an increased degree of masking Fe II. Studies have shown that to mask Fe II $2 \mathrm{nM}$ by $100 \%$ in necessary to use a $10 \mu \mathrm{M}$ solution of bipyridyl. Below this value, the degree of masking decreases to $70 \%$ at a concentration of $2 \mu \mathrm{M}$ bipyridyl while excessive increase of the bipyridyl concentration leads to inhibitory effects for the electrochemical processes.

\section{Experimental part}

Following the laboratory tests, the series of parameters presented in table 1 were selected.

Table 1. Working parameters set for determining total iron in drinking water for different working domain

\begin{tabular}{ll}
\hline Working electrode & HMDE \\
\hline Stirrer & $2000 \mathrm{rpm}$ \\
\hline Purging time & $300 \mathrm{~s}$ \\
\hline Deposition potential & Without deposition \\
\hline Deposition time & $0 \mathrm{~s}$ \\
\hline Equilibration time & $10 \mathrm{~s}$ \\
\hline Pulse amplitude & $50 \mathrm{mV}$ \\
\hline Start potential & $-250 \mathrm{mV}$ \\
\hline End potential & $-600 \mathrm{mV}$ \\
\hline Voltage step & $6 \mathrm{mV}$ \\
\hline Sweeping time & $0,3 \mathrm{~s}$ \\
\hline Peak potential & $-360 \mathrm{mV}$ \\
\hline
\end{tabular}

UV digestion of sample in the presence of hydrogen peroxide and hydrochloric acid is required, prior to analysis, only for groundwater or surface water samples to remove the influence of organic compounds that can either mask and complexate iron or have surfactant properties and thus can be adsorbed on the mercury drop of the work electrode. The working domain was chosen between 10 and 50 micrograms / L.

A calibration curve was drawn, and a sample of tap water was analyzed. The analyzed sample was then enriched with increasing concentrations by standard iron solution. So when plotting the calibration curves or for sample determinations, as such or in enriched sample, at least two replicates for each point on the curve were performed.

Figure 1 shows the voltamogram for iron calibration curve over the range of 10-50 $\mu \mathrm{g} / \mathrm{L}$ obtained after five additions and three replicates and in Figure 2 is shown the calibration curve of total iron in the range $10-50 \mu \mathrm{g} / \mathrm{L}$. 


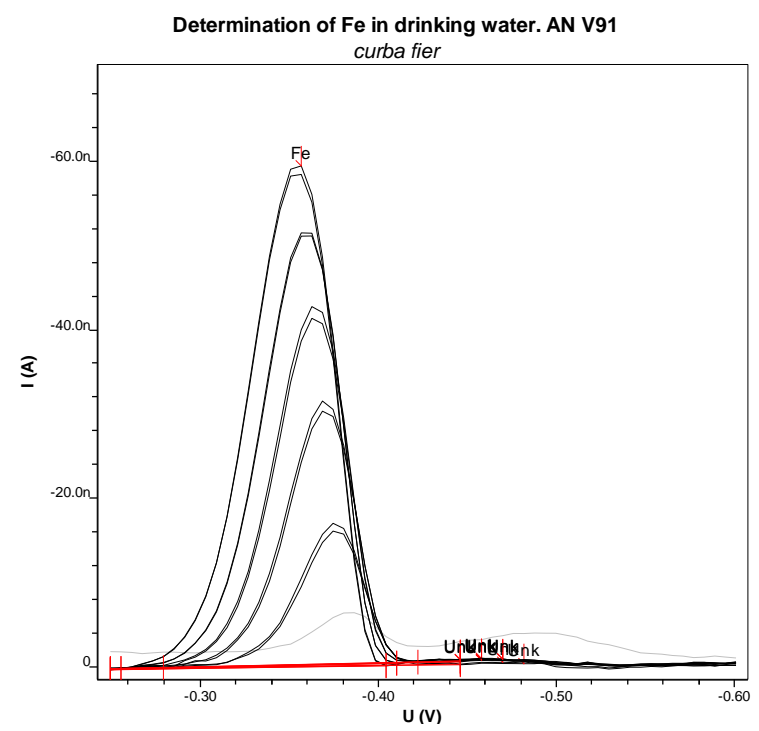

Fig. 1. The voltammogram of the calibration curve

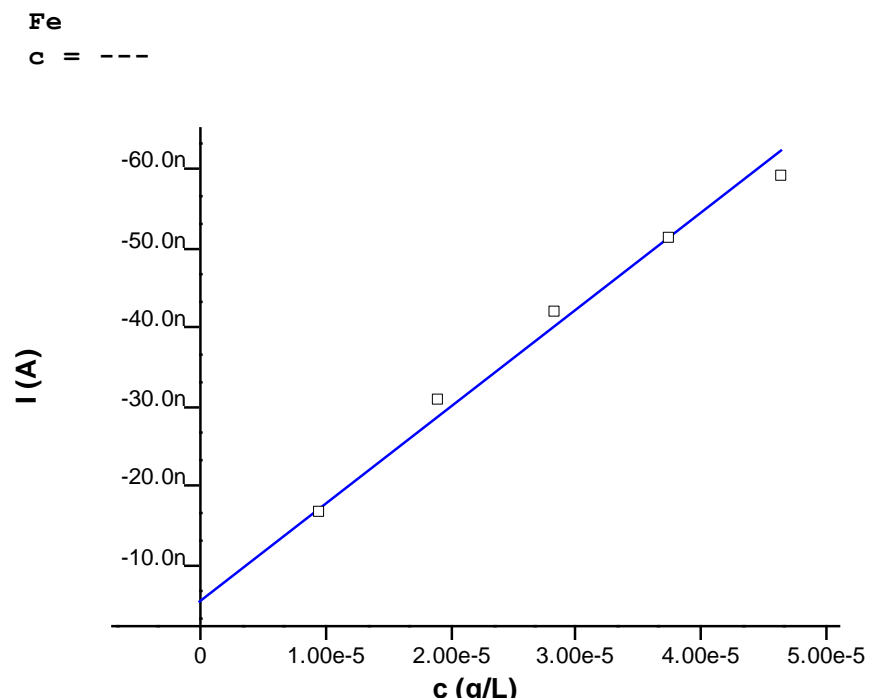

Fig. 2. The calibration curve of total iron in the range $10-50 \mu \mathrm{g} / \mathrm{L}$

For the calibration curve with the field work in the domain of $10-50 \mu \mathrm{g} / \mathrm{L}$, a very good correlation coefficient of 0.994 is obtained. After plotting the calibration curve, tap water sample was subjected to analysis (Fig.3.si Fig.4) 


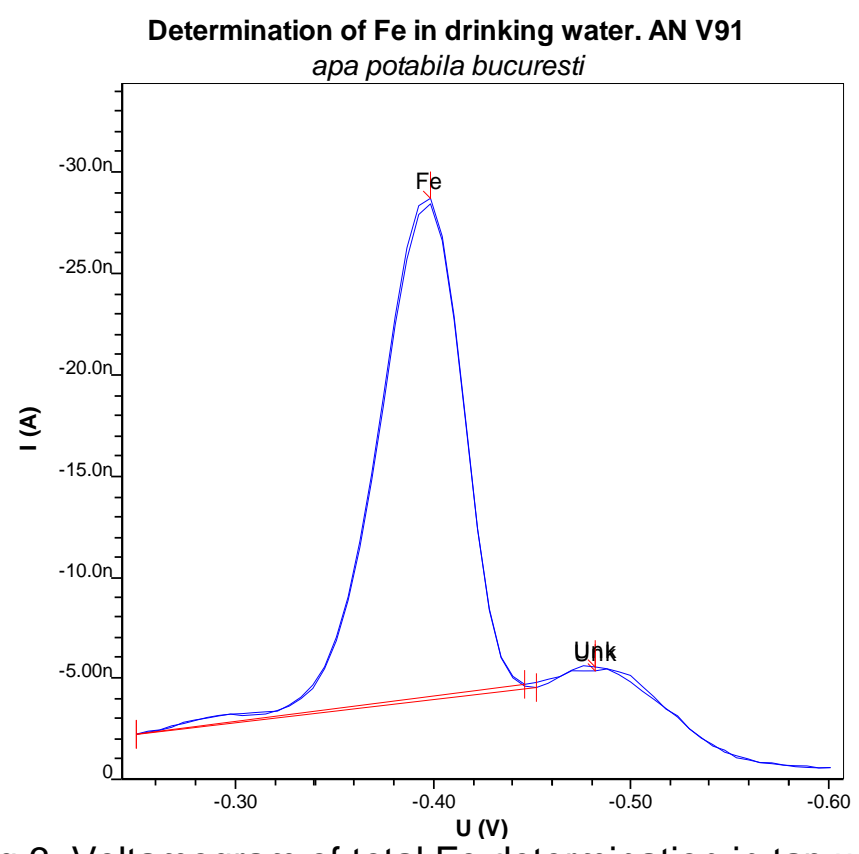

Fig.3. Voltamogram of total Fe determination in tap water

$\mathrm{Fe}=16.191 \mathrm{ug} / \mathrm{L}$

$\begin{array}{lrl}\mathrm{c}= & 16.191 \mathrm{ug} / \mathrm{L} \\ +/- & 0.706 \mathrm{ug} / \mathrm{L}(4.36 \%)\end{array}$

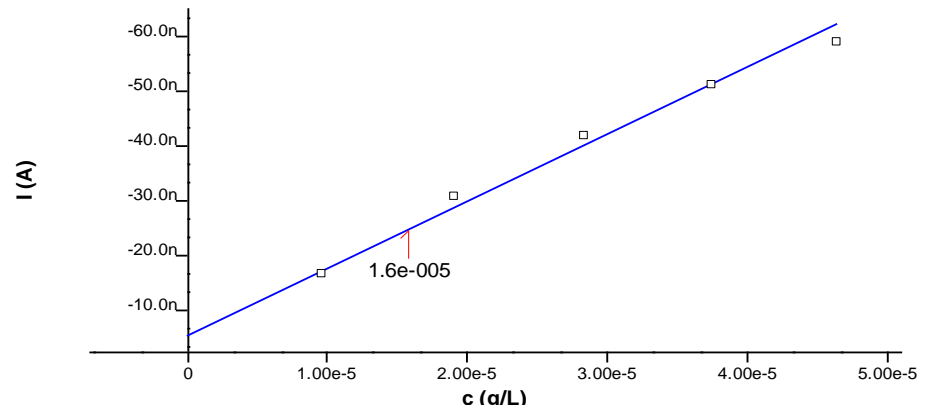

Fig.4. Determination of total iron in tap water

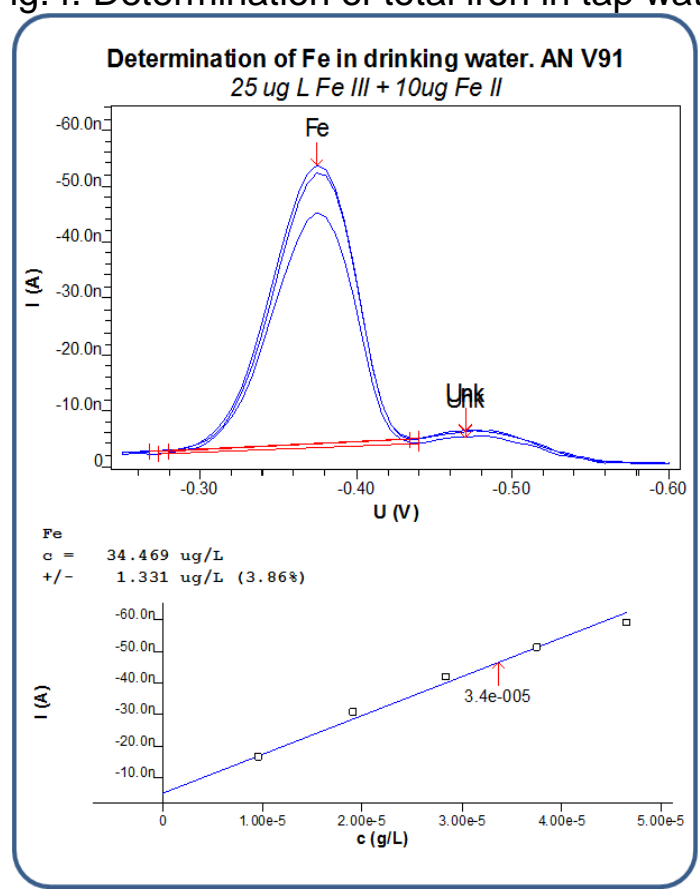

Fig.5. Determination of recovery following the addition of mixed standard solutions 
To test the method for determination of iron species in drinking water, $25 \mu \mathrm{g} / \mathrm{L} \mathrm{Fe} \mathrm{(III)} \mathrm{and} 10 \mu \mathrm{g} / \mathrm{L}$ of $\mathrm{Fe}$ (II) were added. Existing iron in the sample was set as blank, then switched to total iron determination.

After the addition of iron standard solutions, results obtained from three repetitions lead to a value retrieved of $34.47 \mathrm{~g} / \mathrm{L}$. The results are shown in Figure 5 .

The recovery grade is of $98.48 \%$ in case of tap drinking water. The values obtained represent the average of three replicates.

As described above, after determining the total iron in the sample followed the determination of Fe (III). For this purpose, the drinking water was treated with bipyridyl with the purpose of total masking and complexation of the Fe (II). After twenty minutes, the sodium phosphate buffer solution was added and the determination of $\mathrm{Fe}$ (III) was performed. The results are presented in the voltamograms from Fig.6..

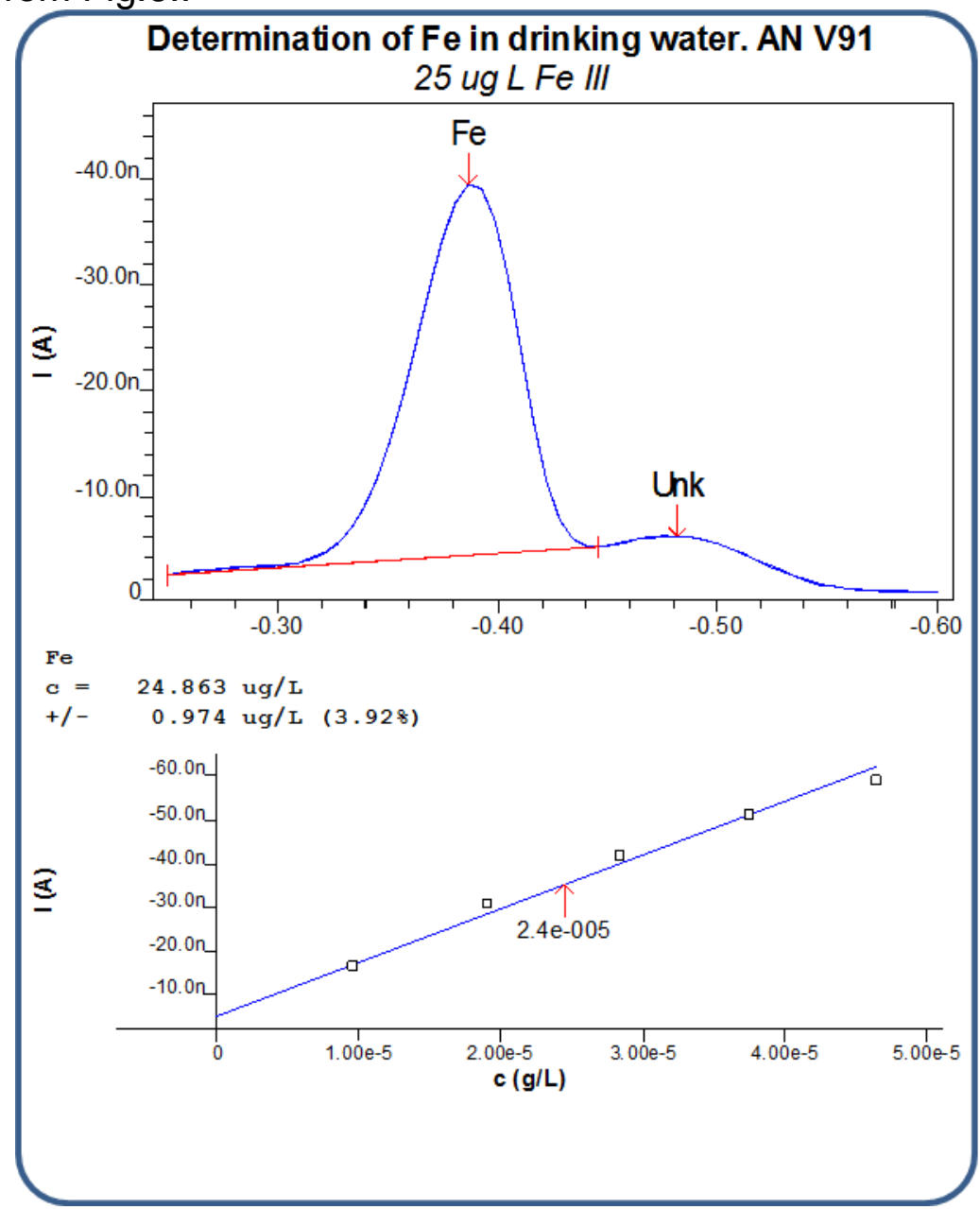

Fig 6. Determination of recovery following the addition of mixed standard solutions and complexation with bipyridyl

The recovery rate obtained after masking $\mathrm{Fe}$ (II) is $99.45 \%$ in the case of tap water. The values obtained represent the average of three replicates.

\section{CONCLUSIONS}

The laboratory tests were conducted using non-standardized methods. The results obtained from laboratory tests prove a very good recovery rate for measurements performed $(98.48 \%$ for the 
determination of total iron and $99.45 \%$ for the determination of Fe (III) by masking Fe (II) with bipyridyl).

The average degree of recovery after all additions and replicates performed, is $98.97 \%$. The correlation coefficient for the calibration curve was 0.994 for the concentration interval of 10-50 $\mu \mathrm{g} / \mathrm{L}$. The method can be applied with confidence for drinking water analysis. The determinations performed using this method are achieved with low costs and requires little time.

\section{Aknowledgments}

The work has been funded by National Authority for Scientific Research and Innovation through Programme Nucleu Environmental research - priority in sustainable industrial development based on knowledge - Environment and Industry, Project PN 09-13.03.03

\section{References}

$1 \quad$ VYDRA, F., STULIC, K., JULACOVA, E., Halsted Press, New. York. - 1976;

2 BUMBAC, C., LEONTE, E.P., DUMITRESCU, C., GHITA, I., STEFANESCU, M., J Environ Prot Ecol., Volume: 11 Issue: 3, 2010, p. 822-829;

3 FAROOQ, M.O., TAIMOOR, A. A., AL-SHAHRANI, S., BALEANU, D., RATHER, S. U., Rev. Chim., 66, No. 4, 2015, p.499-502;

$4 \quad$ FOGG, A.G., WANG, J., Pure Appl. Chem. 1999, V.71, No.71, p 891 -897;

5 POPA D. E., BULEANDRA, M., MURESEANU, M., IONICA, M., TANASE, I. GH. Rev. Chim., 61, Nr. 2, 2010, p. 162-167;

$6 \quad$ GLEDHILL, M., VAN DEN BERG, C. M.G., Mar. Chem., V. 47 (1), 1994, p. 41-54;

7 DOBRE, N., GOLGOVICI, F., ANICAI, L., BUDA, M., Rev. Chim., 65, No.5, 2014, p. 578-581;

$8 \quad$ VAN DEN BERG, C. M. G., Anal. Chem., 2006, 78 (1), pp 156-163;

9 POPA D. E., MURESEANU, M., TANASE, I. GH. Rev. Chim., 63, Nr. 5, 2012, p. 507-512;

10 VAN STADEN, J.F., MATOETOE, M.C., Anal. Chim. Acta, V. 376, (3), 1998, p. 325-330 